\title{
Pengaruh Waktu Pemasangan Kerodong pada Buah Pisang terhadap Serangan Hama Nacoleia octasema
}

\author{
Aulia Anandita ${ }^{{ }^{*}}$, Supriyadi ${ }^{1)}$, dan Retno Wijayanti1 ${ }^{1}$
}

\begin{abstract}
Bagging banana fruits can be develop as a control to protect the fruits from Nacoleia octasema. The objective of this research was to determine the effect and relation of the banana fruit bagging time on $N$. octasema. This research was conducted in Tlogo Orchard, Delik Village, Tuntang District, Salatiga, Central Java from September-November 2018. This research used purposive sampling with 3 banana cultivars and 4 treatment. The observation variable of this research was the incidence of attacks. The results showed that there was an effect on the banana fruit bagging time against the incidence of pest attacks. The average incidence attack showed that the unbagged banana fruits had the biggest attacks. In addition, there was a positive relationship between the banana fruit bagging time and cultivars on the incidence of attacks. The older a banana bagged, the greater incidence of pest attacks. Kepok had the biggest incidence of attacks compared to the other cultivars.
\end{abstract}

Keywords: Alternative Pest Control, Incidence, Scab Pest

\section{PENDAHULUAN}

Pisang (Musa paradisiaca L.) merupakan salah satu komoditas buah yang banyak diminati di Indonesia. Pengembangan komoditas pisang bertujuan memenuhi kebutuhan akan konsumsi buah-buahan seiring dengan bertambahnya jumlah penduduk dan meningkatnya kesadaran masyarakat akan pentingnya gizi dimana pisang merupakan sumber vitamin, mineral dan juga karbohidrat. Menurut data Kementan (2017) bahwa produksi pisang di Indonesia pada tahun 2017 mencapai 7.162.678 juta ton meningkat sebesar 2,22\% dibandingkan pada tahu 2016. Dalam budidaya pisang saat ini terdapat kendala yaitu serangan hama dan penyakit tanaman. Menurut Prahardini et al. (2010) salah satu hama utama yang ada pada tanaman pisang yaitu ngengat kudis (Nacoleia octasema). Hama ini menyerang bunga dan buah muda sehingga meninggalkan bercak seperti kudis pada kulit buah yang sudah tua. Serangan ini memiliki pengaruh yang kecil terhadap hasil buah karena hanya menunjukkan gejala kudis namun dari segi kualitas ini akan berpengaruh terhadap penerimaan konsumen dan harga.

Pengendalian yang tepat perlu dilakukan untuk menurunkan kerusakan hama kudis. Selama pengendalian yang dilakukan adalah dengan memberikan pestisida sehingga dibutuhkan pengendalian lain untuk mengurangi penggunaan pestisida. Pengerodongan adalah pembungkusan buah untuk menghambat kerusakan buah saat masih di pohon yang dapat dilakukan sebagai pengendalian alternatif. Muchui et al. (2010) mengatakan pembungkusan buah pada pisang dapat dilakukan dalam pemeliharaan buah pisang. Cara ini sering dilakukan pada berbagai negara untuk meningkatkan hasil produksi dan kualitas buah

1) Program Studi Agroteknologi, Fakultas Pertanian, Universitas Sebelah Maret (UNS), Surakarta

Author contact : auliaanandita23@gmail.com pisang. Penelitian mengupayakan untuk mengurangi kerusakan buah akibat serangan hama kudis dengan pemasangan kerodong pada bunga pisang. Tujuan penelitian ini adalah untuk mengetahui pengaruh waktu pemasangan kerodong terhadap serangan hama N. octasema.

\section{BAHAN DAN METODE}

Penelitian dilaksanakan di Kebun Buah Tlogo Desa Delik, Kecamatan Tuntang, Salatiga, Jawa Tengah pada bulan September-November 2018. Alat yang digunakan meliputi kain kerodong yang terbuat dari bahan tile. Bahan yang digunakan yaitu tanaman pisang dari 3 kultivar yaitu Mas Kirana, Raja Nangka, dan Kepok.

Penelitian dilakukan dengan metode percobaan lapangan dengan pengambilan sampel secara Purposive Sampling menggunakan 3 kultivar buah pisang dan 4 perlakuan yaitu pemasangan kerodong saat :

$\mathrm{K} 1$ : Sebelum bunga mekar

$\mathrm{K} 2: 7$ hari setelah bunga mekar pertama

$\mathrm{K} 3$ : 14 hari setelah bunga mekar pertama

K4 : tanpa perlakuan

Masing-masing dilakukan sebanyak 3 kali pada tiap kultivar sehingga didapatkan 36 sampel. Variabel penelitian yaitu insidens serangan. Insidens serangan dihitung menggunakan rumus :

Insidens Serangan $=\frac{n}{N} \times 100 \%$

Keterangan $: \mathrm{n}=$ Jumlah buah yang terserang kudis dalam satu tandan, $\mathrm{N}=$ Jumlah buah seluruhnya dalam satu tandan.

Data yang diperoleh dianalisis dengan Uji T, korelasi serta regresi dengan menggunakan perangkat lunak SPSS dan Ms. Office Excell yang disajikan dalam bentuk histogram, tabel dan grafik.

\section{HASIL DAN PEMBAHASAN}

\section{Insidens serangan hama}

Hasil insidens serangan $N$. octasema bila dibandingkan pada tiap kultivar di setiap perlakuan tidak berbeda nyata. Rata-rata serangan terendah pada pemasangan kerodong sebelum mekar berada pada 
kultivar mas kirana sebesar $13,56 \%$, sedangkan tertinggi pada kepok sebesar $24,62 \%$. Rata-rata serangan terendah pada pemasangan kerodong tujuh hari setelah bunga mekar pertama berada pada kultivar raja nangka sebesar $17,58 \%$ dan tertinggi pada Kepok sebesar $27,58 \%$. Pemasangan kerodong pada 14 hari setelah mekar menunjukkan memiliki rata-rata serangan tertinggi pada kultivar Mas Kirana sebesar 39,85\% dan terendah pada Raja Nangka sebesar $27,45 \%$. Buat pisang tanpa kerodong menunjukkan persentase serangan tertinggi berada pada Mas Kirana 50,56\% dan terendah pada Raja Nangka 28,04\% (Gambar 1). Pada seluruh kultivar dan pada seluruh perlakuan yang dilakukan terdapat serangan. Serangan terdapat pada pemasangan kerodong bunga sebelum mekar dapat dikarenakan pada saat sebelum diberi kerodong hama dewasa telah meletakkan telurnya di jantung pisang sebelum mekar. Sehingga hama tetap berkembang dan memakan buah pisang. Hal ini didukung dengan Nelson et al. (2006) yang mengatakan Hama betina dewasa meletakkan telurnya di bunga. Fase larva kemudian masuk ke bunga lalu memakan buah yang tumbuh.

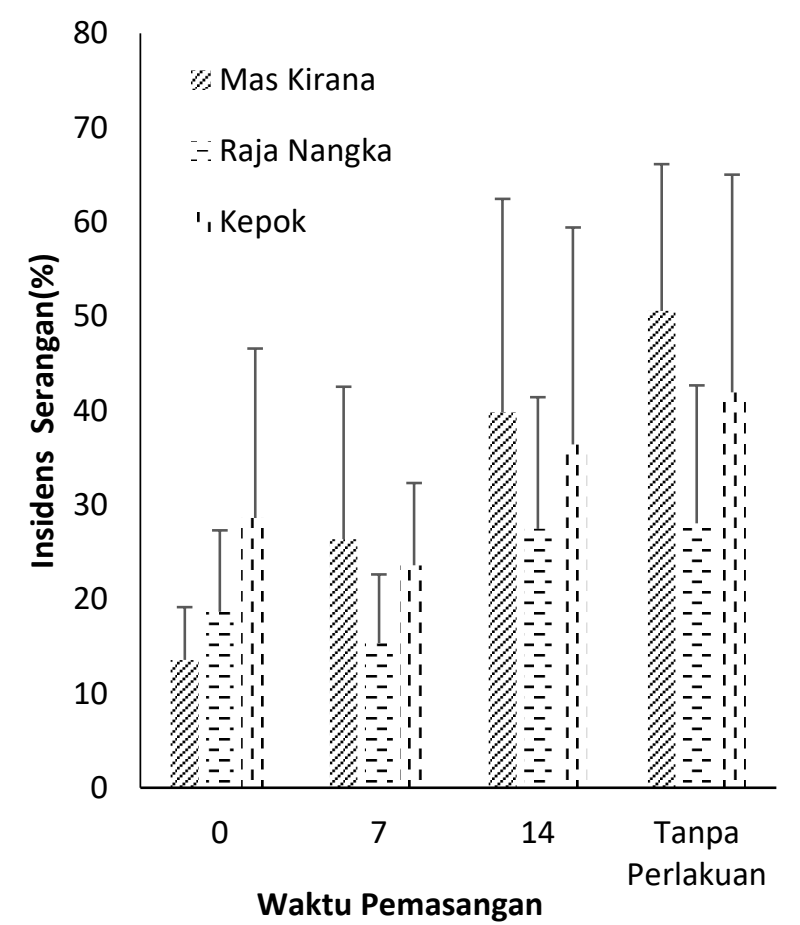

Gambar 1. Histogram insidens serangan N. octasema

Rata-rata serangan berdasarkan faktor waktu pemasangan saja menunjukkan hasil yang berbeda nyata pada perlakuan sebelum mekar dengan 14 hari setelah mekar dan tanpa perakuan. Perlakuan lainnya dilihat tidak berbeda nyata satu dengan lainnya. Berat serangan terendah berada pada pemasangan kerodong sebelum mekar dengan rata-rata sebesar $18,20 \%$. Sedangkan intensitas tertinggi berada pada K4 dengan rata-rata sebesar 40,18\% (Gambar 2).

Hasil rata-rata insidens serangan berdasarkan waktu pemasangan kerodong menunjukkan semakin lama perlakuan mulai dilakukan maka semakin besar pula insidens serangannya. Pembungkusan buah memiliki banyak pengaruh terhadap buah namun dipengaruhi pula oleh beberapa hal. Sharma et al. (2014) mengatakan bahwa pembungkusan buah berpengaruh terhadap ukuran buah, kematangan, warna kulit dan kualitas buah yang mana dipengaruhi pula seperti oleh waktu pembungkusan, jenis bahan kerodong dan respon spesifik kultivar. Menurut Frank (2018) pembungkusan buah dapat mengurangi serangan hama. Perbedaan antara buah yang dibungkus dengan buah tanpa pembungkusan dapat dilihat dari kerusakan yang disebabkan oleh hama maupun faktor yang berpengaruh lainnya. Pengaruh ini dapat meningkatkan penampilan dan kualitas buah. Sarkar et al. (2016) menambahkan serangan hama pada buah yang tidak dibungkus jauh lebih banyak apabila dibandingkan dengan buah yang dibungkus sehingga lebih menarik secara penampilan dan terbebas dari luka akibat serangan.



Waktu Pemasangan

Gambar 2. Histogram insidens serangan berdasarkan waktu pemasangan kerodong

Hama $N$. octasema menyukai berbagai kultivar pisang. Kultivar Kepok memiliki rata-rata serangan tertinggi dibandingkan yang lain. Hal ini berarti kultivar kepok mampu menyediakan cadangan makanan lebih banyak dibandingkan kultivar lainnya. Begitu pun hasil ini tidak berbeda jauh dari Mas Kirana. Preferensi hama memilih untuk inangnya berdasarkan beberapa hal yang mengacu pada jumlah makanan yang mampu disediakan inang. Hapsari et al. (2018) mengatakan hama $N$. octasema cenderung menyukai pisang yang memiliki kulit tebal. Kultivar Kepok memiliki kulit yang lebih tebal dibandingkan lainnya. Selain itu, jumlah sisir juga diduga mempengaruhi kerusakan akibat hama. Semakin banyak sisir yang ada maka hama akan semakin suka. Hal ini berlaku untuk mas kirana yang memiliki lebih banyak sisir meskipun ketebalan kulitnya lebih tipis dari yang lainnya. Banyaknya sisir menurut Hapsari et al. (2018) mempengaruhi kerapatan buah sehingga hama akan semakin senang untuk 
melanjutkan hidupnya dalam kondisi yang lembab dan suhu rendah.

Satyagopal (2014) mengatakan Hama N. octasema menyerang buah pisang pada stadia larva dan berhenti saat fase dewasa. Serangannya meyebabkan adanya bekas luka pada buah muda. Lalu bekas luka tersebut akan berubah warna mejadi hitam. Perkembangan serangan hama ini terlihat dari kultivar berbeda tiap minggunya. Kultivar Mas Kirana dan Raja Nangka terlihat cenderung meningkat dari minggu pertama hingga minggu ke enam. Halnya berbeda dengan Kepok yang terjadi penurunan pada minggu ke lima. Namun serangan hama tertinggi pada ketiga kultivar terdapat pada minggu ke 6 pengamatan (Gambar 3). Hama tanaman bersifat dinamis dan perkembangannya dipengaruhi oleh lingkungan biotik dan abiotik. Berry et al. (2008) mengatakan bahwa telur hama ini akan menetas 3-4 hari, lalu larva masuk ke pisang bagian. Larva hidup selama 11-19 hari dan dilajutkan dengan fase pupa selama 8-10 hari. Fase dewasa hama ini berlangsung selama 3-10 hari.

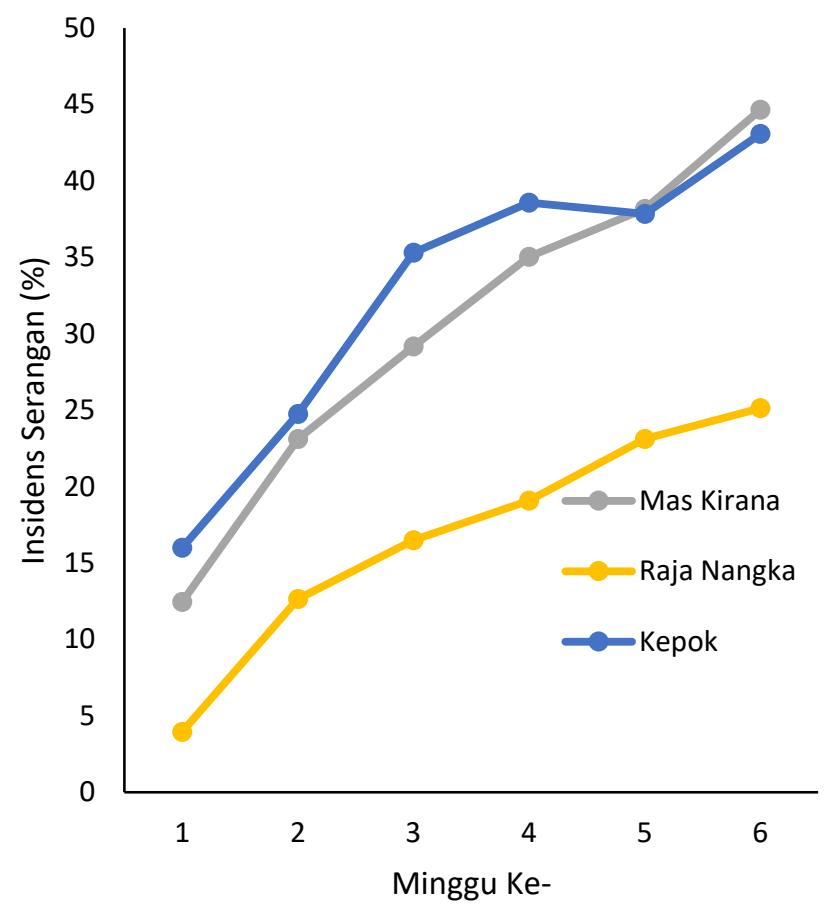

Gambar 3. Perkembangan serangan hama $N$. octasema tiap kultivar Korelasi antara waktu pemasangan kerodong dan
kultivar dengan insidens serangan hama

Hasil analisis korelasi antara Waktu pemasangan kerodong dengan persentase serangan hama menunjukkan korelasi positif yaitu sebesar 0,509. Hasil analisis juga menunjukkan bahwa terjadi pengaruh yang signifikan antara waktu pemasangan terhadap berat serangan pada tingkat kepercayaan $90 \%$. Hasil korelasi antara kultivar dengan insidens serangan hama menunjukkan tingkat korelasi sebesar 0,01 (Tabel 1). Namun variabel kultivar terhadap waktu pemasangan tidak signifikan.
Tabel 1. Korelasi waktu pemasangan kerodong dan kultivar pisang terhadap insidens serangan buah pisang

\begin{tabular}{cccc}
\hline Korelasi & $\begin{array}{c}\text { Insidens } \\
\text { Serangan }\end{array}$ & $\begin{array}{c}\text { Waktu } \\
\text { Pemasangan }\end{array}$ & Kultivar \\
\hline $\begin{array}{c}\text { Insidens } \\
\text { Serangan } \\
\text { Waktu }\end{array}$ & 1,000 & 0,509 & 0,01 \\
$\begin{array}{c}\text { Pemasangan } \\
\text { Kultivar }\end{array}$ & 0,509 & 1,000 & 0,000 \\
\hline Keterangan: & 0,01 & 0,000 & 1,000 \\
\hline Data hasil & pengamatan & dianalisis
\end{tabular}

Korelasi positif pada variabel insidens serangan dengan waktu pemasangan memiliki arti bahwa semakin lama perlakuan mulai diberikan maka intensitas seragan semakin besar. Sesuai dengan penelitian Santosh et al. (2017) pembungkusan buah sebagai pengendalian hama harus dilakukan secepat mungkin. Pemasangan kerodonga yang dilakukan lebih cepat akan mengurangi keruskan yang terjadi. Hal ini diduga karena hama kudis mulai menyerang diawal bunga pisang muncul hingga saat buah pisang masih berumur muda. Hal ini sesuai dengan Susniahti et al. (2005) yang mengatakan bahwa hama ini mulai menyerang pisang saat awal terjadinya pembentukan buah. Pemasangan kerodong memberikan keuntungan yang baik pada kualitas pisang yang dihasilkan. Hal ini didukung pula oleh Weerasinghe dan Ruwanpathirana (2002) pisang yang dilindungi dengan pembungkusan menunjukan tidak adanya luka maupun goresan akibat hama sedangkan buah tanpa dilindungi akan menenjukkan luka fisik.

Korelasi positif juga terjadi pada variabel kultivar dengan insidens serangan hama. Hal ini berarti perbedaan yang ada pada kultivar juga mempengaruhi berat serangan yang diakibatkan $N$. octasema. Sesuai dengan Hapsari et al. (2018) bahwa hama ini menyerang seluruh kultivar pisang yang ada ditandai dengan adanya gejala serangan pada tiap kutivar. Susniahti et al. (2005) menambahkan bahwa hama akan muncul berdasarkan faktor makanan yang ada. Variasi kultivar yang ada memberikan hama makanan yang semakin banyak pula, sehingga populasi hama akan terus bertambah.

\section{Regresi antara waktu pemasangan kerodong dan kultivar dengan insidens serangan hama}

Hasil regresi antara waktu pemasangan kerodong dengan berat serangan hama berbeda tiap kultivarnya. Kultivar Mas Kirana seperti di grafik menunjukkan peningkatan intensitas seiring dengan peningkatan waktu pemasangan. Persamaan kuadrat pada Mas Kirana yaitu $y=-0,52 x^{2}+15,06 x-1,115$ dengan $R^{2}$ sebesar 0,9992. Kultivar Raja Nangka memliki persamaan kuadrat $-0,139 x^{2}+5,165 x+10,50$ dengan $R^{2}$ sebesar 0,8608 . Persamaan kuadrat pada kultivar Kepok yaitu $-0,641 x^{2}+2,874 x+32,60$ dengan $R^{2}$ 0,9779 . Hal ini menunjukkan dari seluruh kultivar $R^{2}$ tertinggi yaitu pada kultivar Mas Kirana meskipun kultivar yang lain tergolong cukup besar pula. Hasil signifikansi dari kultivar Mas Kirana yaitu 0,406, pada Raja Nangka 0,956 dan pasa Kepok sebesar 0,645 (Tabel 2). Hal ini berarti waktu pemasangan kerodong pada kultivar Mas Kirana dan Raja Nangka berhubungan dengan intensitas 
serangan. Sedangkan pada Kepok memiliki hubungan yang cukup erat.

Tabel 2. Regresi Waktu Pemasangan Kerodong dengan Insidens Serangan

\begin{tabular}{ccccc}
\hline \multicolumn{5}{c}{ Waktu Pemasangan } \\
\hline Kultivar & $Y$ & $N$ & $R^{2}$ & $P$ \\
\hline $\begin{array}{c}\text { Mas } \\
\text { Kirana }\end{array}$ & $\begin{array}{c}-0,52 x^{2}+15,06 x \\
-1,147\end{array}$ & 9 & 0,9992 & 0,406 \\
\hline $\begin{array}{c}\text { Raja } \\
\text { Nangka }\end{array}$ & $\begin{array}{c}-0,139 x^{2}+ \\
5,165 x+10,50\end{array}$ & 9 & 0,8608 & 0,956 \\
\hline Kepok & $\begin{array}{c}-0,641 x^{2}+ \\
2,874 x+32,60\end{array}$ & 9 & 0,9779 & 0,645
\end{tabular}

Keterangan : Data hasil pengamatan dianalisis menggunakan uji regresi dan uji signifikansi (P) menggunakan tingkat kepercayaan 95\% $(\alpha=0,05)$

Nilai $R^{2}$ ini menunjukkan pengaruh yang diberikan waktu pemasangan terhadap insidens serangan pada tiap kultivarnya. Hasil ini pula menunjukkan adanya pengaruh lain terhadap serangan hama namun tidak begitu besar. Kerusakan tertinggi bila dilihat dari hasil $R^{2}$ berada pada kultivar Mas Kirana. Artinya waktu pemasangan kerodong ini berpengaruh sebanyak $99,99 \%$ sedangkan sisanya dapat dipengaruhi oleh faktor lainnya. $\mathrm{R}^{2}$ terendah berada pada kultivar Raja Nangka yaitu sebesar $86,08 \%$. Kerusakan tertinggi ini diduga dipengaruhi karena hama yang lebih menyukai kultivar Mas Kirana. Hal ini dapat dikarenakan beberapa hal. Salah satunya yaitu jumlah pisang yang lebih banyak berada pada kultivar Mas Kirana ini. Meskipun begitu hama tetap menyerang kultivar lainnya dikarenakan kultivar lain tetap menyediakan kebutuhan makanan hama. Hal ini didukung dengan pernyataan Heard (1999) bahwa hama akan menyerang inangnya apabila inang tersebut siap untuk menyediakan makanan berdasarkan preferensinya. Faktor lain yang mempengaruhi intensitas serangan dapat pula diduga karena jenis bahan yang digunakan untuk membungkus buah. Menurut Pathak et al. (2017) jenis bahan mempengaruhi hasil dari buah pisang. Hal ini dikarenakan adanya pengaruh perbedaan kelembaban dari tiap jenis bahan.

\section{KESIMPULAN}

Kesimpulan yang dapat diambil yaitu waktu pemasangan kerodong memiliki korelasi yang positif dengan insidens serangan hama $N$. octasema artinya semakin tua umur buah pisang saat diberikan kerodong maka semakin besar pula insidens serangan hama N.octasema. Kultivar Kepok memiliki insidens serangan terbesar sehingga dapat dikatakan paling rentan terhadap hama $N$. octasema dibandingkan kultivar lainnya. Bagian sisir bawah diserang lebih banyak dibandingkan sisir bagian atas dan tengah.

\section{DAFTAR PUSTAKA}

Berry C, Meyer JM, Hoy MA, Heppner JB, Tinzaara W, Gold CS, Baz A. 2008. Banana pests and their management. Encyclopedia of Entomology. 359-369.
Frank DL. 2018. Evaluation of fruit bagging as a pest management option for direct pests of apple. J Insects. 178(9): 1-12.

Hapsari YW, Supriyadi, Retno W. 2018. Serangan hama kudis pisang nacoleia octasema pada beberapa kultivar pisang. J Agrotech Res. 2(2):1-6.

Heard A. 1999. Concept in insect host-plant selection behavior and their application to host specificity testing. Proceedings: Host specificity testing of exotic arthropod biological control agents: The biological basis for improvement in safety. July 4-14. Bozeman, Montana, USA. p10.

Kementan. 2017. Produksi pisang menurut provinsi, 2013-2017. http://www.pertanian.go.id. Diakses 2 Mei 2019.

Muchui MN, Mathooko FM, Njoroge CK et al. 2010. Effect of perforated blue polyethylene bunch covers on selected postharvest quality parameters of tissuecultured bananas (Musa spp.) cv. Williams in central Kenya. J Storeed Products and Postharvest Research. 1(3): 29-41.

Nelson SC, Ploetz RC, Kepler AK. 2006. Musa species (banana and plantain). species profiles for pacific island agroforestry. http://www.traditionaltree.org. Diakses pada 5 Mei 2018.

Pathak P, Ranjit KB, Bhupen KB, Utpal D, Jugabrata D. 2017. A review of works done regarding the impact of bunch cover application in banana. Int. J. Curr. Microbiol. App. Sci. 6(7): 2181-2194.

Prahardini PER, Yuniarti, Krismawati A. 2010. Karakterisasi varietas unggul pisang mas kirana dan agung semeru di kabupaten lumajang. Buletin Plasma Nutfah. 16(2): 126-133.

Santosh DT, Tiwari KN, Reddy RG. 2017. Banana bunch covers for quality banana production. Int $\mathrm{J}$ Curr Microbiol App Scie. 6(7): 1275-1291.

Sarkar S, Ganesh D, Suraj S, Sankar S, Sujan B. 2016. Frontline demonstration on effect of bunch cover in banana for quality production of banana fruits. International Journal Of Green Pharmacy. 10(4):261264.

Satyagopal K. 2014. Banana. India: Balaji Scan.

Sharma RR, Jameel J, Vijay RRS. 2014. Pre-harvest fruit bagging: a useful approach for plant protection and improved post-harvest fruit quality - a review. J Horticultural Sci Biotech. 89(2): 101-113.

Susniahti N, Sumeno, Sudarjat. 2005. Bahan ajar ilmu hama tumbuhan. Universitas Padjadjaran. Bandung.

Weerasinghe SS. Ruwapathirana KH. 2002. Influence of bagging material on bunch development of bananas (Musa spp.) under high density planting system. Annals of Sri Lankan Department of Agri. 4: 47-53. 